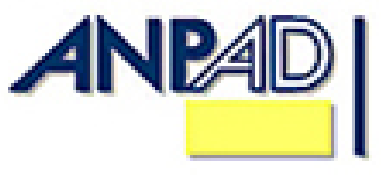

Available online at http://www.anpad.org.br/bar

BAR, Rio de Janeiro, v. 11, n. 3, art. 3, pp. 284-301, July/Sept. 2014 http://dx.doi.org/10.1590/1807-7692bar2014370

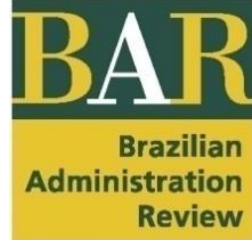

\title{
Understanding Interorganizational Learning Based on Social Spaces and Learning Episodes
}

Anelise Rebelato Mozzato

E-mail address: anerebe@ terra.com.br Universidade de Passo Fundo - FEAC/UPF FEAC/UPF, Campus I UPF-BR 285, Bairro São José, Cx. Postal 611, 99001-970, Passo Fundo, RS, Brazil.

Claudia Cristina Bitencourt E-mail address: claudiacb@unisinos.br Universidade do Vale dos Sinos - UNISINOS Unisinos, Av. Unisinos, 950, Cristo Rei, 93022-000, São Leopoldo, RS, Brazil.

Received $1^{\text {st }}$ July 2013; received in revised form 13 January 2014 (this paper has been with the authors for three revisions); accepted 28 January 2014; published online $1^{\text {st }}$ July 2014. 


\begin{abstract}
Different organizational settings have been gaining ground in the world economy, resulting in a proliferation of different forms of strategic alliances that translate into a growth in the number of organizations that have started to deal with interorganizational relationships with different actors. These circumstances reinforce Crossan, Lane, White and Djurfeldt (1995) and Crossan, Mauer and White (2011) in exploring what authors refer to as the fourth, interorganizational, level of learning. These authors, amongst others, suggest that the process of interorganizational learning (IOL) warrants investigation, as its scope of analysis needs widening and deepening. Therefore, this theoretical essay is an attempt to understand IOL as a dynamic process found in interorganizational cooperative relationships that can take place in different structured and unstructured social spaces and that can generate learning episodes. According to this view, IOL is understood as part of an organizational learning continuum and is analyzed within the framework of practical rationality in an approach that is less cognitive and more social-behavioral.
\end{abstract}

Key words: interorganizational learning; social learning spaces; learning episodes; cooperation; interorganizational relationships. 


\section{Introduction}

Different organizational settings have been gaining ground in the world economy, with a growing number of different forms of strategic alliances (Inkpen \& Tsang, 2007). As a result, organizations are increasingly introducing new settings involving interorganizational relationships with different actors such as organizations, universities and trade associations, etc. (Dacin, Reid, \& Ring, 2008). This constitutes an appropriate strategy when faced with an environment that is becoming more and more uncertain (Human \& Provan, 1997).

In addition to this, a second point highlighting the importance of organizations working from collaborative perspectives, exploring learning (situations) built on relationships between organizations is highlighted by Crossan, Lane and White (1999), where the authors discuss different levels of learning. Crossan, Mauer and White (2011) suggest new studies in the field of interorganizational learning, reinforcing this paper focus's.

Interorganizational learning (IOL) processes have become a relevant field of research, particularly as researchers attempt to understand the scenarios and processes involved in new organizational relationships and settings. It should be pointed out that, however relevant IOL may be, it is still poorly investigated and is best termed a field in progress (Crossan, Mauer, \& White, 2011; Engeström \& Kerosuo, 2007; Inkpen \& Tsang, 2007; Knight \& Pye, 2005; Larsson, Bengtsson, Henriksson, \& Sparks, 1998). The earliest studies dealing with IOL date back to the late 1990s (Larsson et al., 1998) and are still seen as limited in scope, which means that further investigation is of paramount importance (Dierkes, Antal, Child, \& Nonaka, 2001; Easterby-Smith, Burgoyne, \& Araujo, 2001; Easterby-Smith \& Lyles, 2003; Engeström \& Kerosuo, 2007; Greve, 2005; Inkpen \& Tsang, 2007; Nooteboom, 2008).

Indeed Engeström and Kerosuo state that "recent conceptual models of organizational and interorganizational learning tend to be worryingly generalized and common-sensical" (2007, p. 338). Antonello and Godoy $(2009,2010,2011)$ identified gaps in studies on organizational learning and highlighted the need to expand their scope of analysis by identifying learning processes that pervade organizational boundaries, which reinforces the need to introduce additional units of analysis in order to advance this field of knowledge. Considering this, Hardy, Phillips and Lawrence (2003), Greve (2005), Engeström and Kerosuo (2007), Inkpen and Tsang (2007), Nooteboon (2008), Estivalete, Pedrozo and Cruz (2008) and Balestrin and Verschoore (2008) amongst others point out the need to deepen studies on IOL.

With this in mind, the need to put forward some theoretical and empirical reflections, and afford greater depth to studies in the field of IOL is clear. This theoretical essay is based on the assumption that IOL is understood as part of the continuum of Organizational Learning as was proposed by Crossan et al. (1995), Knight (2002), Bapuji and Crossan (2004), Holmqvist (2004), Knight and Pye (2005) and Crossan et al. (2011). Following this line of thought, IOL is understood as a dynamic process that occurs in interoganizational relations of cooperation, in different social spaces (structured and non-structured), stimulating learning situations that will be referred to in this paper as learning episodes.

More specifically, we consider that the practice-based perspective extends the literature on organizational learning by advocating a fourth level of analysis (the interorganizational level) and a fifth process (cooperation) to be added to the three levels of analysis (individual, group and organizational) and the four processes (intuiting, interpreting, integrating and institutionalizing) of the Organizational Learning construct proposed by Crossan et al. (1999).Therefore, our proposed model is based on new evidence gathered from our practice-based approach, taking as a starting point Crossan et al. (1995) and Crossan et al. (2011).

Understanding IOL as part of a multi-level framework of learning, the following research question comes about: How does the process of IOL occur from a practice-based perspective? 
Therefore the objective is to understand IOL, based on a socio-behavioral view, within the logic of practical rationality, without remaining centered on cognitive approaches. With this in mind, we will make use of the based-on-practice or practice-based approach. Gherardi (2006) work on a practicebased approach, contemplating learning as a process and the different levels that occur within this process. Thus, despite the authors' primary concern being with organizational learning, we feel that analyzing IOL through this theoretical lens is innovative, and that it can result in worthwhile insights into the construction of referential concepts around the topic in question. Corradi, Gherardi and Verzelloni (2010) argue that the practice-based perspective has been used as a theoretical lens for reinterpreting many organizational phenomena. This in turn leads to the idea that it is also possible to reinterpret IOL as an interorganizational phenomenon.

Practice-based studies can make a significant contribution to link the analysis of working, learning and organizing because they enable contextualization of organizing within a circumscribed empirical context, define them as a collective practical accomplishment, analyze the activities that contribute to the stabilization and performativity of organizing, and analyze knowledge in knowing (Gherardi \& Souto, 2013).

This theoretical article is structured as follows: following this introduction, as a result of an extensive review of the theory of organizational and interorganizational learning, as well as of studies on interorganizational relationships from 1990 to 2011, the following inquiries regarding IOL are proposed: (a) some reflections about organization and learning that allow us to understand the ontological position proposed by this paper; (b) the multi-level structure of the learning process; (c) Interorganizational Learning as a process-based practice; (d) Interorganizational Learning and cooperation; (e) the range of social spaces that make learning possible. Finally, the contribution and the most important reflections and considerations on the topic and their implications for further research are presented.

\section{Organization and Learning}

The author's understanding of organization follows a positioning of organizing, highlighting the procedural idea, based on an interpretive paradigm.

This ontological position is important in enabling us to understand interorganizational learning that emphasizes relationships and a built process based on organizational practices, in a continuous process. The decision to follow this line of reasoning leads to different views about organization, as highlighted by Czarniawska (2008).

Czarniawska $(2008$, p. 5) points out three main ideas about organization. The first, characterized by the adjective "organized", is related to mechanistic Taylorism and idealist administration theory. In the second idea, the participle "organized" has been replaced by the adjective "organizational", which was inspired by what the author calls "the most fashionable branch of science - cybernetics". However, there is a third position in describing what organization is, and it is exactly this idea that inspired our understanding of organization. We follow Weick's perception of organizing, which focuses on "what people do when they act collectively in order to achieve something" (Czarniawska, 2008, p. 5). In other words, we have opted for a practice-oriented approach to the study of organizational knowing and acting, which indicates movement and process. As Suchman (2000, p. 313) points out, "learning how to be a competent organization member involves learning how to translate one's experience, though acknowledged forms of speaking, writing and other productions, as observably intelligible and rational organizational action".

We justify this point of view by the fact that modern management and learning occur in multiple contexts, though multitudes of kaleidoscopic movements. As Weick (1979) notes, organizing 
happens in many places at once, and organizers move around quickly and frequently. In this scenario organizational learning is gaining ground and attention amongst researchers and practitioners.

OL has been the subject of extensive research in the last few years. Although OL is widely accepted and its importance to the strategic performance of organizations is fully acknowledged, the complexity and diversity of concepts that permeate these studies compound this scenario (Amorim \& Fischer, 2009; Antonacopoulou \& Chiva, 2007; Argote, 2011; Bitencourt, 2005; Easterby-Smith \& Lyles, 2003; Fiol \& Lyles, 1985; Ruas, Antonelo, \& Boff, 2005). The situation of IOL is not different.

While OL is not the main focus of this research, it supports another dimension of this concept, namely IOL. The intraorganizational dimension serves as a basis for the understanding of an interorganizational dimension, with a focus on their intersection (OL and IOL).

Holmqvist (2003, 2004, 2009) claims that the interconnection between intraorganizational and interorganizational learning cannot be dismissed, even though they can be analyzed separately (Larsson et al., 1998). The focus of this theoretical essay is on the type of IOL that takes place in different interorganizational relationships (strategic alliances) within the framework of the multi-level learning process.

\section{Multi-level structure of the learning process}

The necessity to advance the studies on IOL is a natural result of the growing importance of interorganizational relationships. Over the last ten years, the focus of studies on OL has been shifting gradually from intraorganizational learning to multi- and interorganizational learning. Nevertheless this has been achieved at the expense of conceptual developments (Engeström \& Kerosuo, 2007).

In their exploration of OL in the last decade, Crossan et al. (2011) demonstrated the need for studies to be carried out using a multi-level structure, as OL is a phenomenon that takes place on multiple levels, including the external context of the organization and the interorganizational level.

Crossan et al. (1999) propose an analytical framework (Figure 1) for OL with four learning processes (intuiting, interpreting, integrating and institutionalizing) on three levels of analysis. These authors emphasize that these levels are permeated (linked) by both social and psychological processes. Thus, IOL is presented as the fourth level of learning, after the organizational level, inspired in the practice-based perspective. The theoretical framework could be seen in the Figure 1.

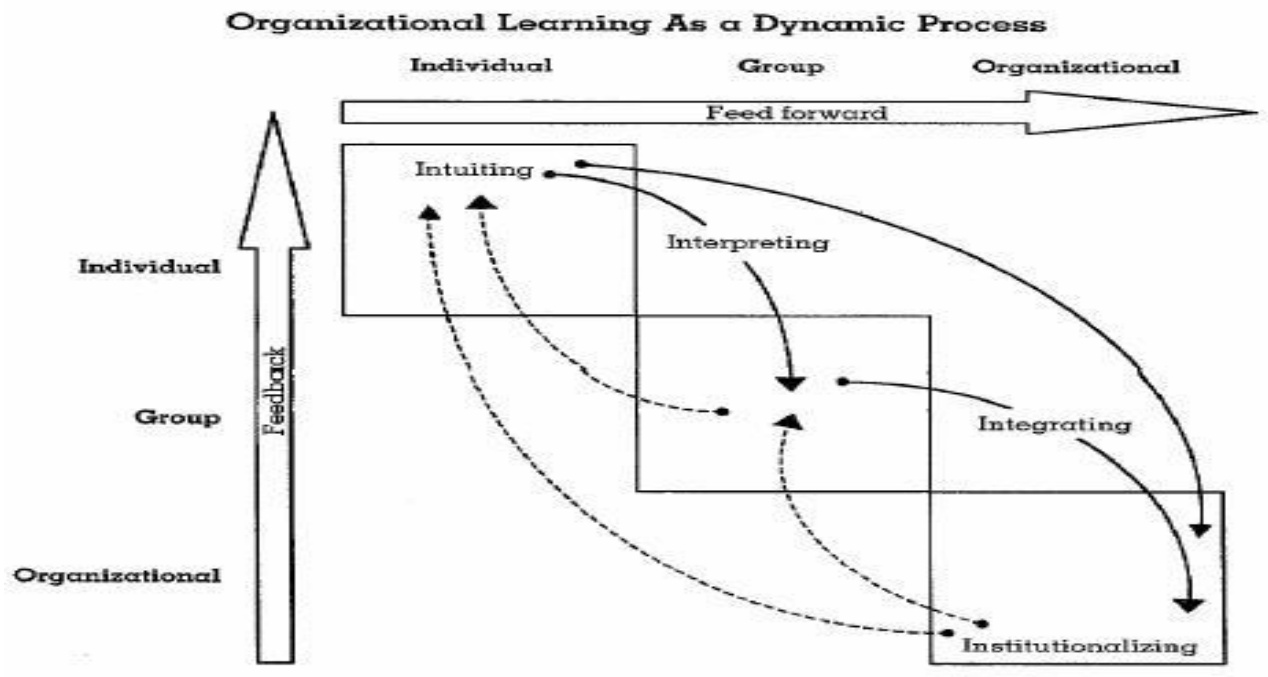

Figure 1. Organizational Learning as a Dynamic Process.

Note. Source: Crossan, M. M., Lane, H. W., \& White, R. E. (1999). An organizational learning framework: from intuition to institution (p. 532). Academy of Management Review, 24(3), 522-537. doi: 10.5465/AMR.1999.2202135 
With the aim of achieving a clearer understanding, IOL will be treated as part of a continuum of organizational learning as identified by Crossan et al. (1995), and Crossan et al.(1999), even though this is not included in the corresponding frameworks presented by these authors. We propose the inclusion of fourth level into the framework elaborated by Crossan et al. (1999) which refers to the analysis of IOL, and which deals with the fifth process on this level, namely cooperation. Figure 2 demonstrates its inclusion in the framework.

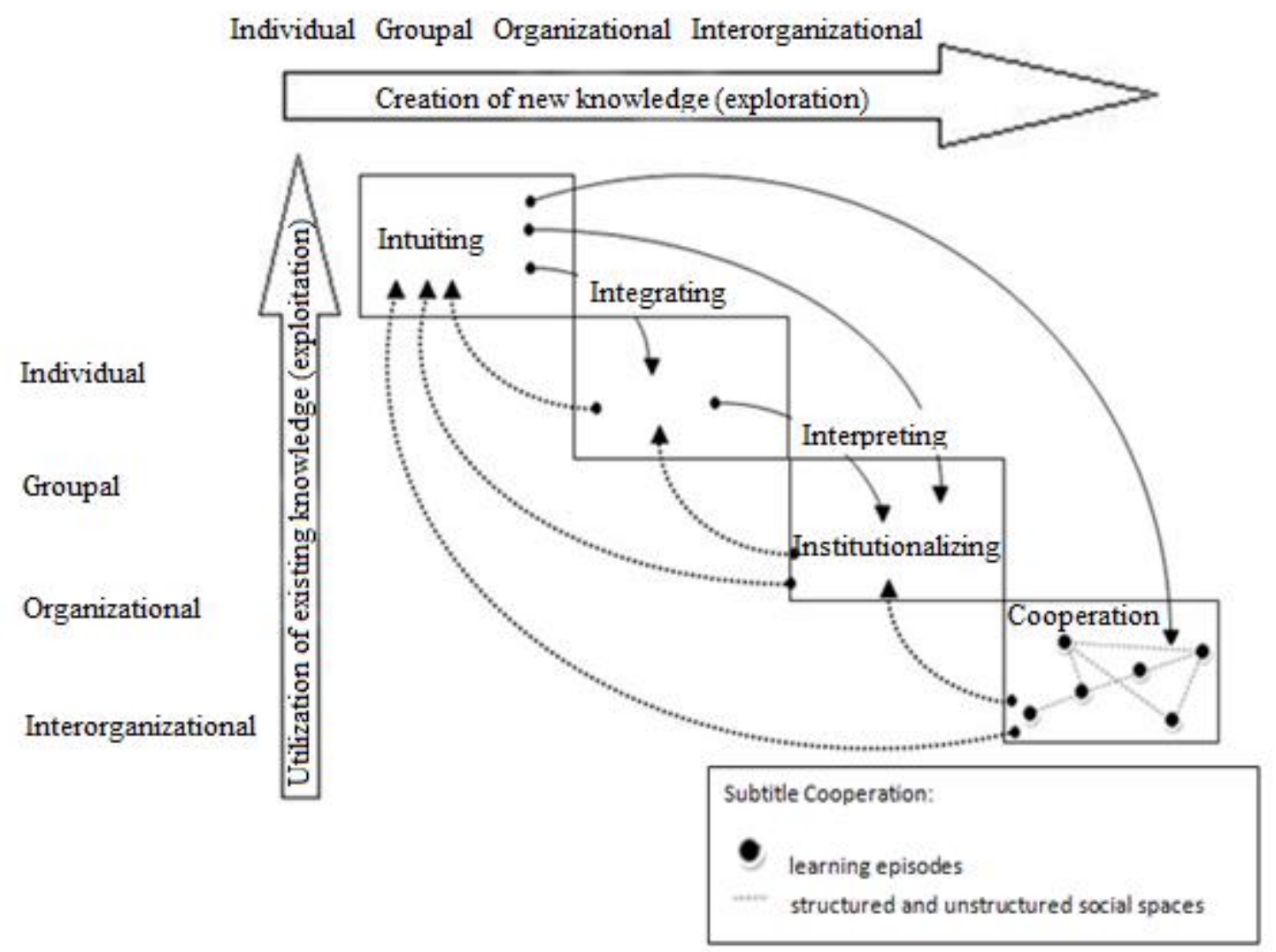

Figure 2. IOL as a Dynamic Process through Co-operation.

Note. Source: Adapted from Crossan, M. M., Lane, H. W., \& White, R. E. (1999). An organizational learning framework: from intuition to institution (p. 532). Academy of Management Review, 24(3), 522-537. doi: 10.5465/AMR.1999.2202135

Building on the ideas in Crossan et al. (1999), the dynamics of this framework is explained with the inclusion of a fourth level of learning - interorganizational learning (IOL). This level of learning deals with relationships established through cooperation between different actors through cooperation. Cooperation, the fifth process included in the framework, is related to relational strategies (assumed to be cooperative) established between the different actors in interorganizational relationships. Such interorganizational relationships happen in structured and non-structured social spaces and they result in learning episodes under a context of cooperation.

Thus, in interpreting the framework dynamics, the first three levels of learning and the four processes involved operate along the lines of the ideas espoused by Crossan et al. (1999). However, with respect to the fourth level and the resulting inclusion of a fifth level, despite following the same logic, it is worth noting that intuition intervenes in integration, which in turn intervenes in interpretation, and that interpretation intervenes in institutionalization. This in turn results in institutionalization interfering in cooperative processes. As a result, cooperation intervenes in institutionalization, which in turn interferes in interpretation. Sequentially then, interpretation intervenes in integration, which ultimately intervenes in intuition. Faced with this dynamic, (movement in both directions), it can be observed that learning takes place over four levels: individual, group, organizational and interorganizational. 
However, inclusion on this fourth level means that the direct interference of intuition on institutionalization (as proposed by Crossan et al., 1999) is transferred to cooperation. Pursuing this line of thought, when the authors propose that institutionalization has a direct effect on intuition, it is understood that cooperation has a direct effect on intuition. Moreover, as they point out, such levels are permeated by social and psychological processes.

Figure 2, as reproduced here, illustrates the multi-level structure characteristics of the learning process, exposing the intimate interconnection between all levels and the fact that they are pervaded by processes that reinforce the importance of approaching learning from a social and behavioral view, from a practice-based approach rather than from a cognitive approach.

Our view follows the reasoning put forward by Marshall (2008), who believes that cognitive theory is not opposed to the practice-based approach, but that it constitutes a limited approach when guided by positivism, tending towards reductionism. Marshall $(2008$, p. 420) corroborates this in stating that, "socially shared cognitions play a crucial part in guiding practices".

Given the fact that learning is an everyday action in the sense that it is the effect of a series of interrelated practices and operations (Corradi, Gherardi, \& Verzelloni, 2010; Sandberg \& Tsoukas, 2011; Styhre, Josephson, \& Knauseder, 2006), it should be noted that learning is closely related to the social-behavioral view (Macdonald \& Crossan, 2010) and that this is a less cognitive approach (Knight \& Pye, 2005). It is believed that viewing learning as a social-behavioral process greatly contributes to a better understanding and advancement of IOL theory, thus expanding the possibilities for analysis based on every day practices.

\section{Interorganizational learning as a process: practice-based perspective}

Larsson, Bengtsson, Henriksson and Sparks (1998) claim that IOL may be seen as the collective acquisition of knowledge between groups of organizations, in this way compassing the idea of interactions between organizations. Therefore, IOL is distinct from OL in that it includes the effects of interactions between organizations, which generates greater synergy and fosters learning.

It is precisely the synergy that results from interactions (cooperation) between organizations that distinguishes interorganizational from intraorganizational learning. Fayard (2008) believes that it is this interaction between actors, which is not limited to organizational boundaries, that give rise to a collective learning environment. Thus, a diversity of bonds is created, generating competitive advantages (Kenis \& Oerlemans, 2008).

IOL is understood as a form of learning that takes place by means of cooperative relationships (interactions) between different agents. These interactions improve and expand each participant's knowledge base and boost the potential to create individual and collective comparative advantages.

It is apparent that many variables affect IOL, showing its complexity, and reinforcing its importance. Therefore, facing this emerging reality (Estivalete, Pedrozo, \& Cruz, 2008), this research field still requires theoretical studies, particularly of an empirical nature, such as those by MacDonald and Crossan (2010), that deal with the learning between different organizations.

Knight and Pye (2005) identify the central role of social interactions in their study of IOL in interorganizational relationships. Along the same lines, Nooteboom (2008) claims that the interactions between different actors in interorganizational settings are an important element in the facilitation of learning and innovation. Child, Faulkner and Tallman (2005) point out that one of the several reasons leading organizations to interact with others is the need to acquire new competencies that can generate innovation with recognized economic market value.

Given IOL's focus, the plurality of the concepts involved and in particular the overlapping and subtle differentiations, this theoretical essay will draw on the concept outlined by Greve (2005, p. 1026): 
Interorganizational learning is a distinctive form of learning because the organization learns from the experience of others rather than from its own experience. While distinctive in the source of learning, interorganizational learning is supported by intraorganizational processes of knowledge creation and retention, and some of its findings parallel those of research on intraorganizational transfer of knowledge.

In order to gain a better understanding of the IOL process, some of the precepts from OL, which explain certain aspects of IOL, will be employed. This draws particularly on Crossan et al. (1999). Pursuing this logic, the question of process-based learning (Easterby-Smith, 1997; Gherardi, 2006) arises - returning to Bitencourt's statement (2010) on how learning occurs through relationships, which is interesting precisely for its process-based perspective of learning and rather than a descriptive perspective.

Lundvall (1992) already understood learning to be a process rather than a product (or stock of knowledge), recognizing the value of interaction and personal contact. Considering that this study returns to a process-based vision of learning at an organizational level, it is necessary to understand action within the social context, in the sense highlighted by Gherardi, Nicolini and Odella (1998), reiterating that learning is inherently a relational activity.

It should be remembered that in the scope of this theoretical essay, learning is defined along the lines of the work developed by Styhre, Josephson and Knauseder (2006), Corradi et al. (2010) and Sandberg and Tsoukas (2011). These authors see learning as an everyday action, a flow of activities that are part of the daily work routine, an effect of a series of interrelated practices and operations that are carried out. In other words, learning happens by means of practical rationality.

Studies making use of a practice-based approach have surfaced in recent years, and can potentially go beyond a conventional organizational analysis (Geiger, 2009). Indeed as Marshall (2008) criticizes a purely cognitive position, Geiger (2009), in addition to the cognitive view, highlights that the practice-based approach also came about as a critique of a positivist and rationalist view of organizations. Both authors however understand that this is not a conflict that necessarily needs to be resolved.

As Geiger (2009) states, the variety of interests and research traditions that are dubbed practicebased studies $^{(1)}$, means that it is not easy to delineate a common perspective. This paper will however also adopt this perspective, with the aim of reaching a better understanding of the IOL process, just as Gherardi (2000) attempted to do in understanding OL.

Something that many practice-based studies have in common is an interest in the collective, situated and provisional nature of knowledge (Gherardi, 2009). In terms of the differences, the same author states that some central questions remain, for example the very concept of practice, and above all, when it is used synonymously with routine.

In situating our work as an attempt to improve understanding of IOL in practice-based theories, we intend to focus our attention on socially-constructed phenomena situated within the fifth process that is delineated in the framework proposed by Crossan et al. (1999) that is to say, interorganizational cooperation. This agrees with Geiger's (2009) view that is oriented towards the subjective, emotional and provisional, as the author considers that practice-based studies call into question the objective, cognitive and abstract nature of knowledge. Also according to Gherardi (2000, 2008, 2009), Nicolini, Gherardi and Yanow (2003), Nicolini (2009) and Gherardi and Souto (2013), organizational learning takes place in practice through participation.

This view of learning as a process at the interorganizational level sees everyday action as an element in the social setting as a whole, in the sense stressed by Gherardi et al. (1998): learning is an inherently relational activity. Referring to Le Boterf (1999), Antonello (2011) states that "everyday situations can become a vehicle for the development of learning processes" (Antonello, 2011, p. 140). 
"Practice-based approaches conceptualize context not simply as a container within which activities occur, but crucially as enacted, whereby its elements are simultaneously influenced by mediums and outcomes of social activity" (Marshall, 2008, p. 419). According to Bispo (2013, p. 22) "practices can be associated with a bricolage work which gathers material, mental, social and cultural elements in a situated context".

Gherardi (2006, p. 47) suggest that "learning is integrated into individuals' daily lives, deriving from informal sources of social relations. It is therefore assumed that any activity can constitute an opportunity for learning and that casual social situations are as important as formal learning experiences".

MacDonald and Crossan (2010) state that behavioral issues have received insufficient attention in spite of the perception that they may help understand learning between different organizations. Therefore, it is believed that an analysis of IOL should not focus solely on cognitive aspects. Such an analysis should rather follow a relational, socio-behavioral assessment that is centered on a process view along the lines of practical rationality. As MacDonald and Crossan state (2010, p. 12): "The integration of new information at the group level makes inter-organizational learning possible. It is the individuals and the social processes and practices, such as dialogue, through which they develop shared understandings that facilitate inter-organizational learning".

In line with this view, these authors identify dialogue as a central element of IOL processes because dialogue creates a shared understanding that facilitates learning. "The more that the structures and mechanisms of engagement between the organizations make sustained dialogue, and hence a kind of joint sensemaking, possible the more likely there will be inter-organizational learning" (Macdonald \& Crossan, 2010, p. 12). Larsson et al. (1998) already advocated that IOL may be hindered by a lack of communication.

Importance is given to dialogue and communication precisely because learning is seen as a process that involves issues of context and interaction. Such interactions, particularly cooperative ones, foster IOL, which takes place through a range of existing interorganizational relationships.

\section{Interorganizational learning and cooperation}

The interorganizational cooperation strategy is linked with several important results. It facilitates the production of new knowledge, fosters innovation and new solutions and helps organizations achieve a more central and competitive position in relation to enterprises that work in isolation. Cooperation as the fifth process included in the Crossan et al. model (1999) is related to relational strategies established between the different actors that are external to the organization, facilitating IOL as a dynamic process.

As Jorde and Teece (1989) point out, these new organizational arrangements offer improved access to new knowledge by facilitating OL, providing access to new technologies and innovation processes and improving technological capabilities. To sum up, different interorganizational arrangements yield gains to the economic actors involved.

The importance of information and, consequently, of knowledge flows is clear, something which is facilitated in a system of interorganizational cooperation. Hardy et al. (2003) discuss the effects of interorganizational cooperation and claim that, in addition to allowing the sharing of knowledge between organizations, this facilitates the production of new knowledge. Shima (2006) underscores how important it is for companies to share resources and information and to increase the flow of information global enterprises now need.

Therefore, it can be said that organizations that assume different organizational arrangements by means of interorganizational relations are also trying to facilitate the spread of knowledge (Child, 2003; Easterby-smith, Lyles, \& Tsang, 2008; Holmqvist, 2004; Inkpen, 2000; Inkpen \& Tsang, 2007; Knight \& Pye, 2005; Lane, 2001; Macdonald \& Crossan, 2010; Powell, 1998). 
Richardson (1972) also emphasized the importance of adding cooperation to the picture by saying that cooperation can be found in different organizational arrangements and contrasted this concept with the idea that the market rules. Ebers and Jarillo (1998), Powell (1998), Cassiolato and Lastres (2003), Muthusamy and White (2005), Balestrin and Verschoore (2008), Zaheer, Gözübüyük and Milanov (2010), among other researchers on the topic of cooperation, also highlight the importance of cooperative strategies in order to improve organizations' performance.

Jarillo (1993) and Ebers and Jarillo (1998) state that collective actions must be considered in strategic terms so that cooperative relationships can become the source of competitive forces. In the same line advocated by Richardson (1972), Jarillo (1993) points out that the atomistic view of traditional models, in which each individual player faces the world by him or herself, may not be the most efficient way to compete. Lubatkin, Florin and Lane (2001), Hardy et al. (2003) and Zaheer et al. (2010) also share this cooperative premise.

Cooperation may be seen as stemming from collaborative actions established in interorganizational relationships, with mutual commitment. However, the idea of competition is not absent in this setting. Even within the logic of cooperation, the coexistence of cooperation and competition is accepted (Jarillo, 1993; Jorde \& Teece, 1989; Nalebuff \& Brandenburger, 1996) as it constitutes an important source of competitive advantage (Cassiolato \& Lastres, 2003; Ebers \& Jarillo, 1998; Kenis \& Oerlemans, 2008; Muthusamy \& White, 2005; Zaheer, Gözübüyük, \& Milanov, 2010). In interorganizational relationships, learning is often seem as a natural result of cooperation (Child, 2003).

IOL is viewed as part of a continuum of organizational learning, thus enlarging the scope of IOL analysis. However, it is also seen as a dynamic process that takes place in cooperative interorganizational relationships, found in the interactions established in different structured and unstructured social spaces. Such social learning spaces are discussed below and the occurrence of learning episodes in them are highlighted.

\section{Different social learning spaces and learning episodes}

Given that this theoretical essay aims to understand the IOL process through interorganizational cooperative relationships, we propose a micro-level analysis in which the various social spaces involved are important to this dynamics. Interorganizational relationships are established in both structured and unstructured social spaces for learning (Janowicz-Panjaitan \& Noorderhaven, 2009), providing learning episodes (Knight \& Pye, 2005).

Janowicz-Panjaitan and Noorderhaven (2009) demonstrate that learning behaviors can be formal (taking the form of planned events) or informal (taking the form of spontaneous interaction), with different repercussions in the IOL process. These authors emphasize that IOL does not always occur spontaneously. As a result, IOL can be stimulated if structural measures are formalized.

Similarly, Wenger (1998) has stressed that in an ordinary interorganizational contexts, informal social interactions are supported by the formal structure. In agreement with this, Knight (2002) stated that studies on IOL require equal focus on the formal and informal aspects of learning, without privileging one over the other. Powell (1998) highlighted formal and informal aspects as subtle elements that need to be thought out, given that neither information nor knowledge are easily transferred by way of license or purchase.

When these opportunities for social interaction are perceived as an obligation and not as a voluntary learning opportunity, people become less willing to interact and formality tends to inhibit informality, leading to a loss of spontaneity (Janowicz-Panjaitan \& Noorderhaven, 2009). These authors assert that both formal and informal social interactions have a positive effect on IOL results, as Contu and Willmott (2003) suggest. They also highlight the complementarity between formal and informal interactions. Even though formality and informality reinforce each other, these relationships 
cannot be said to be perfect complements, given that the positive effect of informalization tends to disappear as the degree of formality increases.

Therefore, while an increase in the extent of informal learning behavior will yield consistent positive effects on formal behavior, additional formalization will have a positive effect on informal learning mechanisms only up to a point (Janowicz-Panjaitan \& Noorderhaven, 2009). The authors show that, as Thompson (2005) advocated in the case of OL, excessive formalization (formal mechanisms), even when used with the intent of stimulating learning, can hinder both informal learning behaviors and IOL.

Therefore, it is clear that social spaces can foster interorganizational relationships, which, in turn, can lead to the occurrence of learning episodes in the flow of everyday activities that take place in formal and informal spaces. More specifically, it is understood that IOL should be analyzed in accordance with Knight and Pye (2005), when they refer to the importance of analyzing context (history, aims and routine), content (changes that took place) and process (actions and intentions, leading to learning episodes).

According to the assumptions demonstrated by Janowicz-Panjaitan and Noorderhaven (2009), these formal spaces in interorganizational settings are essential in fostering IOL, a process, which can also be stimulated by informal spaces. In this line of reasoning, IOL is understood as a process, a result of a flow of everyday activities, which is recurrent in horizontal relationships established between different actors; i.e. within the logic of practical rationality. Such activity flows are what Knight (2002) termed network learning episodes, which, according to the author, offer an appropriate unit of analysis for empirical research, thus improving the understanding of learning in interorganizational relationships.

These learning episodes, according to Knight (2002) and Knight and Pye (2005), are related to the flow of everyday activities that are found both in structured and unstructured spaces. In other words, learning episodes are actions and interactions that take place between different actors and which foster events and learning experiences (learning events), with a direct or indirect impact on different interacting actors.

Such learning episodes can be analyzed for their content, with a focus on what was learned (e.g. the research of Knight \& Pye, 2005). Alternatively, the focus can be on episode occurrences, in which case their importance to the actors involved is analyzed.

It is understood that establishing cooperative relationships between different actors favors the occurrence of learning episodes, triggering IOL. Moreover, each organization's internal dynamics, as well as the nature of the interorganizational dynamics, determine whether IOL will take place (Van Wijk, Jansen, \& Lyles, 2008).

To sum up, it is clear that everyday activities that are carried out according to interorganizational relationships provide structured and unstructured social learning spaces, in which learning events (episodes and experiences) take place (Knight \& Pye, 2005). Such events are perceived as examples of IOL. In other words, interorganizational relationships that take place in structured and unstructured social spaces make learning episodes possible, which are important to the analysis of IOL processes.

In this microanalysis learning episodes occur daily in different social learning spaces through cooperation, as shown in Figure 3. This figure is part of the proposition of the inclusion shown in Figure 2, now exposed singly, and explains the interactions treated in this subsection. 


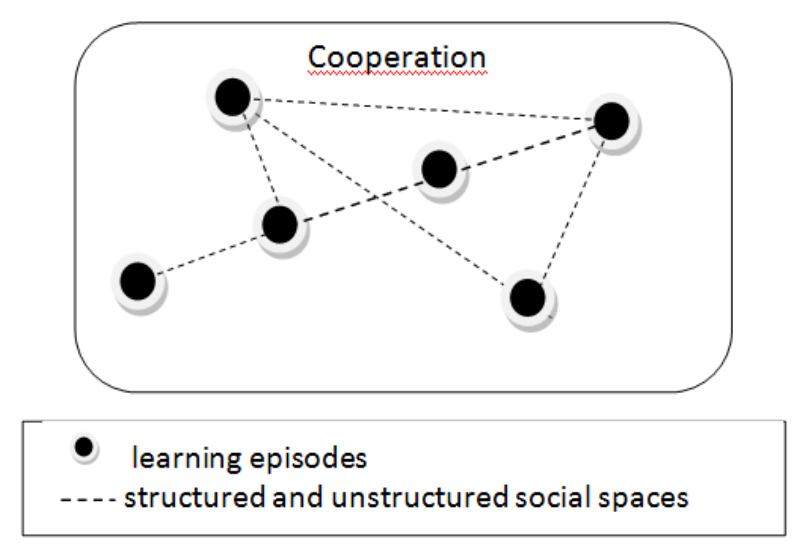

Figure 3. Learning Episodes Occur in Different Social Learning Spaces through Cooperation.

Finally, the existence of barriers that hamper interorganizational relationships is accepted. Some of these barriers are cognitive (social and cultural issues), while others are emotional (attachments, detachments, rivalries, family ties and friendship bonds). They make relationships difficult and thus affect learning. Cognitive barriers and limited emotionality are also implicit control mechanisms that hamper IOL (Child, 2003; MacDonald \& Crossan, 2010).

\section{Final Remarks}

To conclude the proposal presented here, we should emphasize that firstly, the ontological stance taken concerning organizing is best suited for understanding the context and the framework that is proposed in this study. Secondly, IOL features were addressed according to social-behavioral views more than to cognitive approaches, emphasizing the practice-based approach. And thirdly, IOL was analyzed as a dynamic process that takes place in cooperative interorganizational relationships found in different structured and unstructured social spaces in everyday life, that provide learning episodes.

In line with this approach, IOL is understood as part of a multi-level learning structure that is presented as an element of an organizational learning continuum, a level proposed by Crossan et al. (1995), Knight (2002), Bapuji and Crossan (2004), Holmqvist (2004), Knight and Pye (2005) and Crossan et al. (2011). To end this theoretical essay, it can be said that the scope of IOL analysis was expanded by identifying it as the fourth level of learning, with cooperation being the fifth dynamic process in the multi-level structure of the learning process.

Such learning levels are believed to be permeated by social and psychological processes (Crossan et al., 1999), a situation which is not different for the fourth level, IOL. Figure 2 illustrates the multi-level structure of the learning process, revealing the close interconnections between all learning levels. This makes it clear that these levels are permeated by processes that reinforce the importance of dealing with learning by means of a social-behavioral view in which social interactions and context are considered according to the logic of practical rationality. Specifically in relation to the fourth level, that of IOL, we highlight cooperation as a key process for integrating the different organizations basing itself on a set of elements that are both structural (structured and unstructured social spaces), and relational (learning spaces based on interaction).

Thus, stated that understanding the process of IOL is facilitated by its analysis in terms of the occurrence of everyday activities in both structured and unstructured social spaces for learning. Such social spaces lead to cooperative interorganizational relationships, triggering learning episodes that are echoed in differing ways in the process of IOL. 
To conclude, it should be underscored that this research is expected to contribute to the advancement of studies in the field of IOL, making its understanding easier by means of an analysis of learning episodes that take place in different social spaces in which cooperation is ordinary. It is thought that this essay contributed to the advancement of existing knowledge on OL in organizational studies, given that this research contemplates a lesser-known level of analysis, namely interorganizational learning. It may also foster the advancement of the understanding of interorganizational relationships, bringing the field of organizational studies closer to the area of interorganizational relations studies.

We believe that understanding IOL through the lens of practice-based approach can generate important insights, including supporting the interpretive paradigm. The shift in theoretical lens in organizational studies with the use of vision-based practice can help us in the search for a nonfunctionalist paradigm (Nicolini, 2009). Gherardi (2009) corroborates this assertion, highlighting the power of critique of practice-based studies. As a practical contribution, we underline the possibility of stimulating IOL using the proposed model. In this way, organizations will be able to stimulate learning and cooperation between organizations based on the creation of learning spaces that value formal and informal practices.

Although the need for further studies remains, we expect that the debate presented here will contribute to a better understanding and development of IOL, in addition to encouraging further theoretical and empirical research in different interorganizational settings.

As a suggestion for future studies, we propose the application of the framework in the context of collective nature, as in Local Productive Arrangements (LPAs), clusters, joint ventures and other organizational arrangements by means of interorganizational relations.

\section{Note}

\footnotetext{
${ }^{1}$ See Gherardi, S. (2008). Situated knowledge and situated action. In D. Barry \& H. Hansen (Eds.), The SAGE handbook of new approaches in management and organization (pp. 516-525). London: Sage Publications, for a broader view of practicebased studies, (both historical and current). Gherardi, S. (2009). Practice? It's a matter of taste! Management Learning, 40(5), 535-550. doi: 10.1177/1350507609340812. This issue is dedicated to articles that use practice-based theory.
}

\section{References}

Amorin, W. A. C., \& Fischer, A. L. (2009). Aprendizagem organizacional: uma análise sobre o debate e a escolha de categorias para estudos de caso. Perspectiva Contemporânea, 4(1), 101-125.

Antonacopoulou, E., \& Chiva, R. (2007). The social complexity of organizational learning: the dynamics of learning and organizing. Management Learning, 38(3), 277-295. doi: $10.1177 / 1350507607079029$

Antonello, C. S. (2011). Contextos do saber: a aprendizagem informal. In C. S. Antonello \& A. S. Godoy, Aprendizagem organizacional no Brasil (pp. 139-159). Porto Alegre: Bookman.

Antonello, C. S., \& Godoy, A. S. (2009). Uma agenda brasileira para os estudos em aprendizagem organizacional. Revista de Administração de Empresas, 49(3), 266-281.

Antonello, C. S., \& Godoy, A. S. (2010). A encruzilhada da aprendizagem organizacional: uma visão multiparadigmática. Revista de Administração Contemporânea, 14(2), 310-332. Retrieved from http://www.scielo.br/pdf/rac/v14n2/v14n2a08.pdf. doi: 10.1590/S1415-65552010000200008 
Antonello, C. S., \& Godoy, A. S. (2011). Aprendizagem organizacional no Brasil. Porto Alegre: Bookman.

Argote, L. (2011). Organizational learning research: past, present and future. Management Learning, 42(4), 439-446. doi: 10.1177/1350507611408217

Balestrin, A., \& Verschoore, J. (2008). Redes de cooperação empresarial: estratégias de gestão na nova economia. Porto Alegre: Bookman.

Bapuji, H., \& Crossan, M. (2004). From questions to answers: reviewing organizational learning research. Management Learning, 35(4), 397-417. doi: 10.1177/1350507604048270

Bispo, M. (2013). Estudos baseados em prática: conceitos, história e perspectivas. Revista Interdisciplinar de Gestão Social, 2(1), 13-33.

Bitencourt, C. C. (2005). Gestão de competências e aprendizagem nas organizações. São Leopoldo, RS, Brazil: Editora Unisinos.

Bitencourt, C. C. (2010). Gestão contemporânea de pessoas: novas práticas, conceitos tradicionais (2a ed.). Porto Alegre, RS: Bookman.

Cassiolato, J. E., \& Lastres, H. M. M. (2003). O foco em arranjos produtivos e inovativos locais de micro e pequenas empresas. In H. M. M. Lastres, J. E. Cassiolato, \& M. L. Maciel (Orgs.), Pequena empresa: cooperação e desenvolvimento local (pp. 21-34). Rio de Janeiro: Relume Dumará.

Child, J. (2003). Learning through strategic alliances. In M. Dierkes, A. B. Antal, J. Child, \& I. Nonaka (Eds.), Handbook of organizational learning and knowledge (part VI, pp. 657-680). United States: Oxford University Press.

Child, J., Faulkner, D., \& Tallman, S. (2005). Cooperative strategy: managing alliances, networks, and joint ventures (2nd ed.). New York: Oxford University Press.

Contu, A., \& Willmott, H. (2003). Re-embedding situatedness: the importance of power relations in learning theory. Organization Science, 14(3), 283-296. doi: 10.1287/orsc.14.3.283.15167

Corradi, G., Gherardi, S., \& Verzelloni, L. (2010). Through the practice lens: where is the bandwagon of practice-based studies heading? Management Learning, 41(3), 265-283. doi: $10.1177 / 1350507609356938$

Crossan, M. M., Lane, H. W., White, R. E., \& Djurfeldt, L. (1995). Organizational learning: dimensions for a theory. International Journal of Organizational Analysis, 3(4), 337-360. doi: $10.1108 / \mathrm{eb} 028835$

Crossan, M. M., Lane, H. W., \& White, R. E. (1999). An organizational learning framework: from intuition to institution. Academy of Management Review, 24(3), 522-537. doi: 10.5465/AMR.1999.2202135

Crossan, M. M., Mauer, C. C., \& White, R. E. (2011). Reflections on the 2009 AMR decade award: do we have a theory of organizational learning? Academy of Management Review, 36(3), 446-460.

Czarniawska, B. (2008). Organizing: how to study it and how to write about it. Qualitative Research in Organizations and Management: An International Journal, 3(1), 4-20. doi: $10.1108 / 17465640810870364$

Dacin, T., Reid, D., \& Ring, P. S. (2008). Alliances and joint ventures: the role of partner selection from an embeddedness perspective. In S. Cropper, M. Ebers, C. Huxham, \& P. S. Ring (Eds.), Inter-organizational relations (pp. 90-117). Oxford: Oxford University Press. 
Dierkes, M., Antal, A. B., Child, J., \& Nonaka, I. (2001). Handbook of organizational learning and knowledge. New York: Oxford University Press USA.

Easterby-Smith, M. (1997). Disciplines of organizational learning: contributions and critiques. Human Relations, 50(9), 1085-1113. doi: 10.1177/001872679705000903

Easterby-Smith, M., \& Araujo, L. (2001). Aprendizagem organizacional: oportunidades e debates atuais In M. Easterby-Smith, J. Burgoyne, \& L. Araujo, Aprendizagem organizacional $e$ organização de aprendizagem (pp. 15-38). São Paulo: Atlas.

Easterby-Smith, M., \& Lyles, M. A. (2003). The blackwell handbook of organizational learning and knowledge management. Oxford: Blackwell Publishing.

Easterby-Smith, M., Lyles, M. A., \& Tsang, E. W. K. (2008). Inter-organizational knowledge transfer current themes and future prospects. Journal of Management Studies, 45(4), 677- 690. doi: 10.1111/j.1467-6486.2008.00773.x

Ebers, M., \& Jarillo, J. C. (1998). The construction, forms, and consequences of industry networks. International Studies of Management \& Organization, 27(4), 3-21.

Engeström, Y., \& Kerosuo, H. (2007). From workplace learning to inter-organizational learning and back: the contribution of activity theory. Journal of Workplace Learning, 19(6), 336-342. doi: $10.1108 / 13665620710777084$

Estivalete, V. F. B., Pedrozo, E. A., \& Cruz, L. B. (2008). The learning process in interorganizational relationships. Brazilian Administration Review, 5(4), 319-331. Retrieved from http://www.scielo.br/pdf/bar/v5n4/v5n4a06.pdf. doi: 10.1590/S1807-76922008000400006

Fayard, P. (2008). Apresentação. In A. Balestrin \& J. Verschoore (Eds.), Redes de cooperação empresarial: estratégias de gestão na nova economia (pp. IX- XII). Porto Alegre: Bookman.

Fiol, C. M., \& Lyles, M. A. (1985). Organizational learning. The Academy of Management Review, 10(4), 803-813. doi: 10.5465/AMR.1985.4279103

Geiger, D. (2009). Revisiting the concept of practice: toward an argumentative understanding of practicing. Management Learning, 4O(2), 129-144. doi: 10.1177/1350507608101228

Gherardi, S. (2000). Practice-based theorizing on learning and knowing in organizations: an introduction. Organization, 7(2), 211-23. doi: 10.1177/135050840072001

Gherardi, S. (2006). Organizational knowledge: the texture of workplace learning. Malden, MA, Oxford, UK, Victoria, Australia: Blackwell publishing.

Gherardi, S. (2008). Situated knowledge and situated action. In D. Barry \& H. Hansen (Eds.), The SAGE handbook of new approaches in management and organization (pp. 516-525). London: Sage Publications.

Gherardi, S. (2009). Practice? It's a matter of taste! Management Learning, 40(5), 535-550. doi: $10.1177 / 1350507609340812$

Gherardi, S., Nicolini, D., \& Odella, F. (1998). Toward a social understanding of how people learn in organizations: the notion of situated curriculum. Management Learning, 29(3), 273-298. doi: $10.1177 / 1350507698293002$

Gherardi, S., \& Souto, P. C. N. (2013, setembro). What do people do when they work? The contribution of practice-based studies to the understanding of working and organizing. Anais do Encontro Nacional da Associação Nacional de Pós-Graduação e Pesquisa em Administração, Rio de Janeiro, RJ, Brasil, 37. 
Greve, H. R. (2005). Inter-organizational learning and heterogeneous social structure. Organization Studies, 26(7), 1025-1047. doi: 10.1177/0170840605053539

Hardy, C., Phillips, N., \& Lawrence, T. B. (2003). Resources, knowledge and influence: the organizational effects of interorganizational collaboration. Journal of Management Studies, 40(2), 321-347. doi: 10.1111/1467-6486.00342

Holmqvist, M. (2003). A dynamic model of intra-and interorganizational learning. Organization Studies, 24(1), 95-123. doi: 10.1177/0170840603024001684

Holmqvist, M. (2004). Experiential learning processes of exploitation and exploration within and between organizations: an empirical study of product development. Organization Science, 15(1), 70-81. doi: 10.1287/orsc.1030.0056

Holmqvist, M. (2009). Complicating the organization: a new prescription for the learning organization? Management Learning, 40(3), 275-287. doi: 10.1177/1350507609104340

Human, S. E., \& Provan, K. G. (1997). An emergent theory of structure and outcomes in small-firm strategic manufacturing networks. Academy of Management Journal, 40(2), 368-403. doi: $10.2307 / 256887$

Inkpen, A. C. (2000). Learning through joint ventures: a framework of knowledge acquisitions. Journal of Management Studies, 37(7), 1019-1045. doi: 10.1111/1467-6486.00215

Inkpen, A. C., \& Tsang, E. W. K. (2007). Learning and strategic alliances. The Academy of Management Annals, 1(1), 479- 511. doi: 10.1080/078559815

Janowicz-Panjaitan, M., \& Noorderhaven, N. G. (2009). Trust, calculation, and interorganizational learning of tacit knowledge: an organizational roles perspective. Organization Studies, 30(10), 1021-1044. doi: 10.1177/0170840609337933

Jarillo, J. C. (1993). Strategic networks: creating the borderless organization. Oxford: ButterworthHeinemann.

Jorde, T. M., \& Teece, D. J. (1989). Competition and cooperation: striking the right balance. California Management Review, 25-37.

Kenis, P., \& Oerlemans, L. (2008). The social network perspective: understanding the structure of cooperation. In S. Cropper, M. Ebers, C. Huxham, \& P. S. Ring (Eds.), The Oxford handbook of inter-organizational relations (pp. 289-312). Oxford: Oxford University Press.

Knight, L. (2002). Network learning: exploring learning by interorganizational networks. Human Relations, 55(4), 427-454. doi: 10.1177/0018726702554003

Knight, L., \& Pye, A. (2005). Network learning: an empirically derived model of learning by groups of organizations. Human Relations, 58(3), 369-392. doi: 10.1177/0018726705053427

Lane, C. (2001). Organizational learning in supplier networks. In M. Dierkes, A. B. Antal, J. Child, \& I. Nonaka (Eds.), Handbook of organizational learning and knowledge (pp. 699-715). United States: Oxford University Press.

Larsson, R., Bengtsson, L., Henriksson, K., \& Sparks, J. (1998). The interorganizational learning dilemma: collective knowledge development in strategic alliances. Organization Science, 9(3), 285-305. doi: 10.1287/orsc.9.3.285

Le Boterf, G. (1999). L'ingénierie des compétences. Paris: Les editions d'organisation. 
Lubatkin, M., Florin, J., \& Lane, P. (2001). Learning together and apart: a model of reciprocal interfirm learning. Human Relations, 54(10), 1353-1382.

Lundvall, B.-A. (1992). National innovation systems: towards a theory of innovation and interactive learning. London: Pinter Publishers.

MacDonald, P., \& Crossan, M. (2010, June). Learning to innovate: the process of learning between diverse organizations. Proceedings of Organisational Learning, Knowledge and Capabilities Conference 2010, Boston, Massachusetts, USA, 5.

Marshall, N. (2008). Cognitive and practice-based theories of organizational knowledge and learning: incompatible or complementary? Management Learning, 39(4), 413-435. doi: $10.1177 / 1350507608093712$

Muthusamy, S. K., \& White, M. A. (2005). Learning and knowledge transfer in strategic alliances: a social exchange view. Organization Studies, 26(3), 415-441. doi: 10.1177/0170840605050874

Nalebuff, B. J., \& Brandenburger, A. M. (1996). Co-opetição. Rio de Janeiro, RJ: Editora Rocco.

Nicolini, D. (2009). Zooming in and out: practices by switching theoretical lenses and trailing connections. Organizations Studies, 30(12), 1391-1418. doi: 10.1177/0170840609349875

Nicolini, D., Gherardi, S., \& Yanow, D. (2003). Introduction: towards a practice-based view of knowing and learning in organizations. In D. Nicolini, S. Gherardi, \& D. Yanow (Eds.), Knowing in organizations: a practice-based approach (pp. 3-31). New York: Sharpe.

Nooteboom, B. (2008). Learning and innovation in inter-organizational relationships. In S. Cropper, M. Ebers, C. Huxham, \& P. S. Ring (Eds.), The Oxford handbook of inter-organizational relations (pp. 307-634). Oxford: Oxford University Press.

Powell, W. W. (1998). Learning from collaboration: knowledge and networks in the biotechnology and pharmaceutical industries. California Management Review, 40(3), 228-240. doi: $10.2307 / 41165952$

Richardson, G. B. (1972). The organisation of industry. Economic Journal, 82(327), 883-896.

Ruas, R., Antonello, C. S., \& Boff, L. H. (2005). Aprendizagem organizacional e competências: os novos horizontes da gestão. Porto Alegre: Bookman.

Sandberg, J., \& Tsoukas, H. (2011). Grasping the logic of practice: theorizing through practical rationality. Academy of Management Review, 36(2), 338-360.

Shima, W. T. (2006). Economia de redes e inovação. (2006). In V. Pelaez \& T. Szmrecsányi (Orgs.), Economia da inovação tecnológica (Cap. 14, pp. 333-364). São Paulo: Editora HUCITEC/Ordem dos Economistas do Brasil.

Styhre, A., Josephson, P-E., \& Knauseder, I. (2006). Organization learning in non-writing communities: the case of construction workers. Management Learning, 37(1), 83-100. doi: $10.1177 / 1350507606060983$

Suchman, L. (2000). Organizing alignment: a case of bridge-building. Organization, 7(2), 311-327. doi: $10.1177 / 135050840072007$

Thompson, M. (2005). Structural and epistemic parameters in communities of practice. Organization Science, 16(2), 151-164. doi: 10.1287/orsc. 1050.0120 
Van Wijk, R., Jansen, J. J. P., \& Lyles, M. A. (2008). Inter- and intra-organizational knowledge transfer: a meta-analytic review and assessment of its antecedents and consequences. Journal of Management Studies, 45(4), 830-853. doi: 10.1111/j.1467-6486.2008.00771.x

Weick, K. (1979). The social psychology of organizing (2nd ed.). Reading, MA: Addison'Wesley.

Wenger, E. (1998). Communities of practice: learning, meaning, and identity. Cambridge: Cambridge University Press.

Zaheer, A., Gözübüyük, R., \& Milanov, H. (2010). It's the connections: the network perspective in the interorganizational research. Academy of Management Perspectives, 24(1), 62-77. 